\title{
Notaries Role Analysis in Implementation of Credit Agreements \& Defaults Settlement with Guaranteed Liability
}

\author{
Octantina Widiyastuti ${ }^{*}$, Amin Purnawan ${ }^{* *}$ and Siti Ummu Adillah ${ }^{* * *}$ \\ *) Faculty of Law, Universitas Islam Sultan Agung (UNISSULA) Semarang, E-mail: \\ octantinawidiyastuti@gmail.com
}
$\left.{ }^{* *}\right)$ Faculty of Law, Universitas Islam Sultan Agung (UNISSULA) Semarang, E-mail: amin.p@unissula.ac.id
${ }^{* * *}$ Faculty of Law, Universitas Islam Sultan Agung (UNISSULA) Semarang, E-mail: ummu@unissula.ac.id

\begin{abstract}
Analysis of the Role of a Notary in the Implementation of Credit Agreements and Efforts to Settle Default with Guaranteed Mortgage at Bank BRI, Tegal City requires the assistance of a Notary. This happens because the Notary is authorized to make a form of authentic deed that is able to provide legal protection to the parties to the agreement. Regarding the authority of a Notary as a general official making an authentic deed, it can be seen in the provisions of Article 15 paragraph (1) of Act No.: 30 of 2004 concerning the Position of a Notary. The objectives of this journal research are one, to identify and analyze the role of a Notary in a credit agreement with mortgage guarantees at Bank BRI Tegal City Branch Office; two, to find out and analyze the factors causing the occurrence of Default in the credit agreement with the guarantee of Mortgage at Bank BRI Tegal City Branch Office; three, to find out and analyze how to settle defaults in credit agreements with mortgage guarantees at Bank BRI Tegal City Branch Office. The approach method used is the sociological juridical method, the research specifications used are analytical descriptive, using observation and interviews, secondary data collection techniques using library research, and data analysis methods using qualitative analysis. The results of the research and discussion, First, the role of the Notary in the implementation of the credit agreement, as an official authorized to make an authentic deed who is burdened with responsibility in connection with his work in making the deed and the deed can provide legal certainty for the parties in the credit agreement so that the Notary is to prioritize the balance between the namely rights and obligations of the parties who appear before the Notary. Second, the factors causing the occurrence of Default in the credit agreement with guaranteed mortgage rights at Bank BRI Tegal City Branch Office, there are internal factors and external
\end{abstract}


factors causing non-performing loans. Third, Settlement of default in the credit agreement with collateral rights at the BRI bank Tegal City Branch Office can be done by using rescheduling, reconditioning, and restructuring methods.

Keywords: Role; Notary; Credit Agreement; Default.

\section{Introduction}

One of indicator the increasing wheels of the economy in Indonesia are currently marked by various factors, one of which is the increase in business activities that have a direct impact on increasing business by business actors, but this increase is not always followed by good financial capabilities of business actors. Business actors in meeting their financial needs are carried out in various ways, one of which is borrowing funds or capital known as credit, either through state banks or private banks. The existence of borrowing and borrowing money has long been known in people's lives who have known money as a means of payment. ${ }^{1}$

In the bank credit agreement, the role of the Notary through the deed he made provides legal certainty for the parties, namely the bank as the creditor and the customer as the debtor. This legal certainty guarantees the rights and obligations of each party in the credit agreement as stated in the authentic deed. This is because the authentic deed made by and before a Notary is a perfect means of proof.

Judging from the interests of the bank in the bank credit agreement, the position and role of the Notary is needed to keep the implementation of the credit agreement running smoothly so that the bank avoids the risk of loss. Smooth means that credit returns do not experience problems such as bad credit. For this reason, a Notary is also needed in the binding of collateral/collateral at the Bank. Collateral is needed to ensure the smooth return of credit by customers or debtors.

Regarding the authority of a Notary as a general official making authentic deeds, it can be seen in the provisions of Article 15 paragraph (1) of Act No.: 2 of 2014 concerning Amendments to Act No.: 30 of 2004 concerning the Position of a Notary, which states that: Notaries are authorized to make authentic Deeds regarding all actions, agreements, and stipulations required by laws and regulations and/or desired by interested parties to be stated in authentic Deeds, guarantee certainty of the date of making the Deed, save the Deed, provide grosse, copies and quotations of the Deed, all of this as long as the making of the deed is not assigned or excluded to other officials or other people stipulated by law".

${ }^{1}$ www.tegalkota.go.id, accessed on September 28, 2020 at 19.15 WIB 
Mortgage rights are security rights imposed on land rights as referred to in Act No. 5 of 1960 concerning Basic Agrarian Regulations, including or not including other objects which are an integral part of the land, for repayment of debts, certain creditors, which gives priority to certain creditors over other creditors. ${ }^{2}$ Debtor in the Mortgage agreement with the bank, the creditor in this case the bank can execute the Mortgage.

Based on the description above, the formulation of the problem in this study is one, how is the role of a notary in a credit agreement with a mortgage guarantee at BRI Bank Tegal City Branch Office. Two, what are the factors that cause Default in the credit agreement with the guarantee of Mortgage at the BRI Bank Tegal City Branch Office. Three, how is the settlement of default in the credit agreement with the guarantee of Mortgage at Bank BRI, Tegal City Branch Office.

\section{Research Methods}

The approach method used is the sociological juridical method, the research specification used is descriptive analytical, types and sources of data used, primary data and secondary data, which include primary legal materials, secondary legal materials and tertiary legal materials. Primary data collection techniques using observation and interviews, secondary data collection techniques using literature studies, and data analysis methods using qualitative analysis.

The objectives to be achieved in this journal research are the first to find out and analyze the role of a notary in a credit agreement with a mortgage guarantee at BRI Bank Tegal City Branch Office. Second, to find out and analyze the factors causing the occurrence of Default in the credit agreement with the guarantee of Mortgage at Bank BRI Tegal City Branch Office. Third, to find out and analyze how to resolve disputes in credit agreements with mortgage guarantees at Bank BRI Tegal City Branch Office.

\section{Result and Discussion}

\subsection{The Role of a Notary in a Credit Agreement with Mortgage Guaranteed at Bank BRI Tegal City Branch Office}

Based on the results of interviews with Mr. Christian, Bachelor of Law, Master of Notary, as a Notary in the City of Tegal, the role of a notary in a credit agreement, namely through the deed he made, must provide legal certainty for the parties, namely the bank as the creditor and the customer as the debtor.

\footnotetext{
2Purwadi Patrik and Kashadi, 2001, Hukum Jaminan, Fakultas Hukum Universitas Diponegoro, Semarang, p. 14
} 
Legal certainty in this case is to guarantee the rights and obligations of each party in the credit agreement as stated in an authentic deed and binding on the parties and also applies as a law. This is because the authentic deed made by and before a Notary is a perfect means of proof. ${ }^{3}$

There are 3 (three) groups of legal subjects, namely the appearers or interested parties, witnesses and the notary. In this case, the Notary is not a party in making the deed. The Notary is only an official who because of his authority to make an authentic deed according to the wishes of the parties/appearers.

The appearers who come to the notary because of the wishes or the will (wilsvorming) of the parties themselves. The appearers come to the notary so that their legal actions or actions are formulated into an authentic deed in accordance with the authority of the notary, then the notary makes a deed at the request or desire of the appearers, so in this case it provides the basis for the notary and the appearers there has been a legal relationship.

Notary bank partners are notaries who are trusted by banks to carry out credit contracts between banks and debtors. The cooperative relationship between a notary and a bank is made in the form of a cooperation agreement. The cooperation agreement is to perform certain services that can be qualified as a contractual relationship. The cooperation agreement regulates the appointment of a notary, scope of services, notary obligations, payments, statements and guarantees from a notary, confidentiality, term of agreement, termination of agreement, correspondence, compensation, bank name and logo, provisions regarding prevention of bribery, force majeure, applicable law and dispute resolution and general provisions. The Bank and the notary hereby agree to make and sign the cooperation agreement with the terms and conditions that, the Bank hereby appoints a notary to provide services to the bank based on the cooperation agreement and the notary hereby accepts the appointment of the bank partner ${ }^{4}$. In a notary cooperation agreement with a bank, the parties have their respective rights and obligations that must be fulfilled. The notary's obligations to the bank are regulated in the bank partner cooperation agreement, namely: ${ }^{5}$

a. Provide services to the bank every working day, both in the making of a notarial deed/deed of a land deed official (PPAT), as well as other services according to the priority of time and the needs of the bank.

\footnotetext{
${ }^{3}$ Christian, SH., M.Kn, Notary in Tegal City, personal interview on June 15, 2021.

${ }^{4}$ Deen, Thaufiq., Ong Argo Victoria \& Sumain. (2018). Public Notary Services In Malaysia. JURNAL AKTA: Vol. 5, No. 4, 1017-1026. Retrieved from http://jurnal.unissula.ac.id/index.php/akta/article/view/4135

${ }^{5}$ Ibid.
} 
b. Provide minutes of deed and other required documents according to the Bank's request no later than 2 (two) working days or in very urgent circumstances 1 (one) working day.

c. Submit a copy of the deed no later than 7 (seven) working days after signing the minutes of deed

d. Make deeds in accordance with the Bank's request or use the draft provided by the Bank and always maintain and pay attention to the security and interests of the Bank.

e. Checking the certificate (as collateral for mortgage) at the local National Land Office.

f. Complete the mortgage registration process no later than 3 (three) months from the signing of the mortgage granting deed (APHT).

g. Submit a statement letter regarding the certificate management process land rights by stating the settlement period to the Bank (covernote).

The cooperation agreement between the Bank and the Notary is close to an agreement to perform certain services. Because it fulfills the elements of a work agreement, namely doing certain work, under orders, with wages and within a certain time. Notaries must prioritize the balance between the rights and obligations of the parties who appear before the Notary. ${ }^{6}$ This is based on Article 16 paragraph (1) letter a UUJN, namely Notaries are required to act by protecting the interests of the parties. Notaries are required to provide services in accordance with the provisions of Article 16 paragraph (1) letter d UUJN unless there is a reason to refuse it.

The notary must ensure that the deed made is in accordance with the legal rules that have been determined, so that the interests concerned are protected by the deed. The notary is only in charge of recording or writing down in the deed anything explained by the parties, has no right to change or reduce. ${ }^{7}$

In practice, a Notary performs a job based on the authority and duties of his position based on the Law of the Republic of Indonesia Number 2 of 2014 concerning Amendments to Act No. 30 of 2004 concerning the Position of a Notary. The appearers come to the Notary on their own conscience and express their wishes before the Notary, which is then poured into the form of a Notary

${ }^{6}$ Supriadi, Etika \& Tanggung Jawab Profesi Hukum di Indonesia, (Jakarta: Sinar Grafika, 2006), p. 52.

${ }^{7}$ Op.cit. 
deed according to the applicable law and it is impossible for a Notary to make a deed without a request from anyone. As long as the Notary carries out his duties in accordance with the UUJN and has complied with all the procedures and requirements in making the deed, and the deed in question is also in accordance with the parties who appear before the Notary, there will be no prosecution in the form of an unlawful act based on Article 1365 of the Civil Code. ${ }^{8}$

The Notary's attitude in the Indonesian Notary Code of Ethics has set out several rules that must be adhered to by a Notary (other than UUJN), the Notary's relationship with the client must be based on:

1. Notaries provide services to people who need their services as well as possible.

2. Notaries provide legal counseling to achieve high legal awareness, so that community members are aware of their rights and obligations.

3. Notaries must provide services to underprivileged members of the community.

Based on the description above, in order to achieve legal certainty, the author in analyzing the role of a notary in the implementation of credit agreements using the theory of legal certainty according to Sudikno Mertukusumo, legal certainty is a guarantee that a law must be carried out in a good way. Legal certainty requires efforts to regulate law in legislation made by authorized and authoritative parties, so that these rules have a juridical aspect that can guarantee legal certainty to function as a rule that must be obeyed.$^{9}$ In the credit agreement deed to realize a legal certainty, the role of a notary in the implementation of a credit agreement is very important, especially in making a credit agreement deed which is an authentic deed that has perfect evidentiary value. Legal certainty here is that the credit agreement deed made by a notary must clearly and in detail contain:

a. The amount of the credit score.

b. The size of the flower.

c. Credit term.

d. Credit withdrawal terms.

${ }^{8}$ Ibid.

9 Asikini Zainal, 2012, Pengantar Tata Hukum Indonesia, Jakarta, Raja Wali Press, p. 27. 
e. Credit repayment procedures.

f. Credit guarantee/collateral.

g. Rights and obligations of the parties.

h. Other conditions that are common in credit agreements.

In order to fulfill the legitimacy and legal requirements that can protect the legal interests of the parties / parties in the credit agreement and bind the parties and also apply as a law for the parties in the credit agreement to achieve legal certainty for the parties.

\subsection{Factors Causing the Occurrence of Default In Credit Agreements With Guaranteed Mortgage At Bank BRI Tegal City Branch Office}

Based on the results of the author's interview with Mr. Yunanto Dwi Harry Laksono, as AAccount Officer NPL Bank BRI Tegal Branch Office as an informant (resource) from the field research that the author has done, then the factors causing the occurrence of Default in the credit agreement with collateral rights at Bank BRI Tegal City Branch Office is as follows:

1. Broadly speaking, the factors that can become obstacles to the occurrence of non-performing loans can be classified into internal factors and external factors, the Bank's internal factors as the causes of non-performing loans include: ${ }^{10}$

a. Lack of ability or sharpness of the bank to analyze the debtor's business for the feasibility of the credit request submitted by the debtor.

b. Weak credit information systems and credit monitoring and administration systems.

c. The binding of credit guarantees is less than perfect.

2. There are 4 (four) kinds of external factors as the cause of non-performing loans, namely: ${ }^{11}$ :

a. Debtor's business failure;

\footnotetext{
${ }^{10} \mathrm{Mr}$. Yunanto Dwi Harry Laksono, as An Account Officer NPL Bank BRI Tegal Branch Office, personal interview on June 16, 2021.

${ }^{11}$ lbid.
} 
b. Declining economic activity and high lending rates;

c. Utilization of an unhealthy competitive climate in the banking world by irresponsible debtors, and;

d. The disaster that befell the debtor company.

In addition to the factors mentioned above, according to Mr. Yunanto Dwi Harry Laksono, as Aaccount officer NPL Bank BRI Tegal Branch Office, there are factors beyond the control of the debtor, for example: ${ }^{12}$

a. The debtor dies.

In the case of the debtor dies, the debtor's debt remains the responsibility of his heirs, unless at the time of execution of the credit agreement the debtor asks for insurance registration coverage for the debtor.

b. Business the debtor experiences a fire or natural event (natural disaster).

In this case, Bank BRI Kota Tegal cannot provide coverage, because insurance coverage is only given to the collateral/object of mortgage (credit guarantee).

From factors beyond control, Bank BRI Kota Tegal continues to provide considerations to continue to help debtors, these considerations include policies that are sought to ease the burden on debtors.

Based on the description above, for the sake of achieving a legal protection, the authors analyze if there is a default in the implementation of credit agreements using the theory of legal protection, legal protection here is for the aggrieved party, namely the Bank caused by the negligence of the debtor for repayment of his debt. Legal protection that can be carried out by the Bank is by implementing the execution of the mortgage on the object of the mortgage that is pledged by the debtor as collateral for the settlement of the debtor's debt, the object of the mortgage can be in the form of:

a. Right of ownership.

b. Building rights.

c. Cultivation Rights.

${ }^{12} \mathrm{Ibid}$. 
The certificate which is the object of the mortgage is bound by the deed of granting the mortgage which is carried out at the same time as the implementation of the credit agreement and then registered at the local National Land Agency (BPN) office so that a mortgage certificate is issued. The mortgage certificate serves as legal protection for the Bank as the holder of the mortgage, and the mortgage certificate is also a tool to carry out the execution of the mortgage that has executorial power, so that if the debtor defaults, the mortgage guarantee is ready to be executed as is the case with a court decision with legal force. The execution of this mortgage object is a form of legal protection given to the creditor (bank) if the debtor defaults.

\subsection{Settlement of Default in the Credit Agreement with Guaranteed Mortgage at Bank BRI Tegal City Branch Office}

Based on the results of the author's interview with Mr. Yunanto Dwi Harry Laksono, as an account officer NPL Bank BRI Tegal Branch Office as an informant (resource person), the settlement of non-performing loans, especially defaults in credit agreements with banking institutions with mortgage guarantees, that settlement can be carried out amicably is an effort to settle loans based on an agreement between the bank and the debtor who still has good faith and is cooperative in the settlement effort. Then for further settlement efforts, collections are carried out by visiting the debtor directly, and the debtor is asked to make payments in a certain amount of his obligations to the bank within a certain period of time as outlined in the debtor's statement letter.

Settlement of disputes in credit agreements with mortgage guarantees at Bank BRI Tegal City Branch Office can be done using the following methods:

1. Rescheduling Is an effort to save credit by changing the terms of the credit agreement by making changes to the credit repayment schedule or time period, including the grace period, including the amount of the installment or not.

2. Reconditioning Is an effort to save credit by making changes to all the terms of the credit agreement which is not limited to changes in the installment schedule or credit period, but these changes without providing additional credit or without converting all or part of the credit into company equity.

3. Restructuringls a rescue effort by changing the terms and conditions in the credit agreement or converting all debtor credit into company equity.

Implementation of Mortgage Execution is carried out if the debtor is in default in the credit agreement, that the bank does not directly execute, but still tries to take a persuasive approach to the customer. This approach is carried out so that 
as far as possible a peaceful settlement of non-performing loans is obtained without going through execution. For this reason, efforts to save credit that can be carried out by banks are: Rescheduling, Reconditioning, and Restructuring. The litigation process will be taken by the bank, if the debtor's customer has bad intentions, then based on the Mortgage Certificate which guarantees the debtor's credit, execution can be carried out according to Act No. 4 of 1996, but in practice there must be an execution approval from the Head of the District Court.

As for the procedures/measures for the settlement of the debtor's Default on the credit agreement Bank BRI Tegal City Branch Office sequentially are as follows: ${ }^{13}$

1. Billing (call/site visit).

Bank BRI Tegal City Branch Office will collect directly to the debtor by telephone (call) or through a visit to the debtor's house (site visit) to request that the debtor carry out credit payment obligations in the form of credit installment payments so that loans classified as non-performing return to current loans.

\section{Letter of Reprimand (Summary).}

If the call/site visit billing from the bank is not responded to by the debtor who is in default, then the next step is: Bank BRI Tegal City Branch Office will issue a letter of warning (summation) to the debtor. This subpoena is carried out starting from the subpoena stage 1 (one), if the summons is not also responded to by the debtor, a second subpoena will be given. If the second subpoena is also not responded to, a third summons will be given.

\section{Credit Rescue Efforts (Restructuring).}

If the debtor has been summoned 3 (three) times in a row but the debtor does not have good intentions to fulfill the provisions of the credit agreement, then as the next step for the settlement of the debtor's Default, Bank BRI Tegal City Branch Office will try to make credit rescue efforts. Credit rescue is one step to settle bad loans caused by default by the debtor through renegotiation between the bank and the debtor by warning that the terms of credit repayment are expected to the debtor to have the ability to return to credit settlement. Credit rescue can be done if the debtor is cooperative in finding a solution for credit settlement and the debtor's business still has good faith.

\footnotetext{
${ }^{13}$ Ibid.
} 
Credit Rescue Efforts (Restructuring), according toMr. Yunanto Dwi Harry Laksono, as AAccount Officer NPL Bank BRI Tegal Branch Office, is currently an alternative for business actors affected by COVID-19, because with Restructurisation business actors are given a little leeway by extending the credit period, or by reducing interest rates with a certain time limit.

4. Execution of Mortgage In a credit agreement with a mortgage guarantee on Bank BRI Tegal City Branch Office, efforts to settle the debtor's Default through the execution of mortgages had to be carried out because credit settlements through collection, subpoenas and efforts to save credit (restructuring) were not successful.

Mortgage execution is carried out by Bank BRI Tegal City Branch Office by carrying out the registration procedure at the State Assets and Auction Service Office (KPKNL), by attaching a Credit Agreement, Deed of Granting Mortgage and a letter of application for auction on the authority of the mortgage holder (Bank) for the auction of the mortgage object which is the debtor's credit guarantee through the Office State Assets and Auction Service (KPKNL).

\section{Closing}

Based on the description above, in order to achieve justice, the author in analyzing the settlement of default in credit agreements with mortgage guarantees at Bank BRI Tegal City Branch Office using the theory of justice. The theory of justice here is that the bank does not carry out the execution immediately, but the bank still tries to take a persuasive approach to the debtor/customer. This approach is carried out so that as far as possible a peaceful settlement of non-performing loans is obtained without going through execution. The settlement effort can be done by using rescheduling, reconditioning, and Restructuring is a policy in this case to get justice and become a middle point because justice is essentially to seek a common and impartial search so as to get the same sense of justice for the bank and the debtor to obtain a common welfare. Justice for debtors is to obtain policies from banks, especially for debtors whose businesses are feeling overpowered, something that happens outside the control of the debtor, such as the place of business experiencing a natural disaster, or caused by the debtor's death. The policy must be assessed with fairness for the parties to obtain a balance of interests between the bank and the debtor. The author considers the need for the principle of balance to realize justice for the parties in a credit agreement in banking. If the principle of balance in question is not fulfilled, then according to the theory of justice, the credit agreement becomes unbalanced or one-sided, so 
that it can violate the principle of balance. Based on the theory of fairness, these criteria can be interpreted as the basis for the validity of the agreement, especially in banking credit agreements. Justice is the principle of balance (equality) that should be considered in addition to the principle of agreement (consensus), the principle of binding force (pacta sunt servanda) and the principle of freedom of contract.

\section{References}

Journals:

[1] Ana Tasia Pase ,Upaya Hukum Yang Dilakukan Oleh Bank Terhadap Nasabah Yang Melakukan Wanprestasi Perjanjian Kredit Usaha Perdesaan (Kupedes) Pada Bank Bri Unit Ketahun Ditinjau Dari Asas Keseimbangan , Jurnal Hukum Sehasen Vol.2 No.2 November 2019.

[2] Arya Dominika, Dwi; Wiryawan, I Wayan. Akibat Hukum Wanprestasi Dalam Perjanjian Kredit Bank. Kertha Semaya : Journal IImu Hukum, [S.L.], V. 4, N. 3, Feb. 2016. ISSN 2303-0569. Available At: <Https://Ojs.Unud.Ac.Id/Index.Php/Kerthasemaya/Article/View/18910>. Date Accessed: 26 July 2021.

[3] Deen, Thaufiq., Ong Argo Victoria \& Sumain. (2018). Public Notary Services In Malaysia. JURNAL AKTA: Vol. 5, No. 4, 1017-1026. Retrieved from http://jurnal.unissula.ac.id/index.php/akta/article/view/4135

[4] Fathiyah. Eksekusi Jaminan Hak Tanggungan Nasabah Wanprestasi Akad Musyarakah Dalam Perspektif Perlindungan Konsumen.Jurnal Hukum Replik Volume 7 Nomor 1 March 2019.

[5] Frengky Baneftar. Wanprestasi Dalam Perjanjian Kredit Perbankan Dengan Jaminan Sertifikat Tanah Ditinjau Dari Undang-Undang Nomor 4 Tahun 1996: Studi Pada Bank Papua Cabang Biak .Jurnal Ilmu Hukum KyadirenVolume 3 Nomor. 1, January 2020, Halaman1740AvailbleOnlineAt:Https://Journal.Stihbiak.Ac.Id/Index.Php/K yadiren/Article/View/25e-ISSN: 2715-5038 P-ISSN:2502-5058 
[6] Irsyadul Anam Malaba, "Pluralitas Organisasi Notaris di antara Hak, Kebutuhan, Inefiensi dan Tafsir Pemerintah". Jurnal Renvoi, Nomor 2. 26. III Tahun Ketiga 2005.

[7] Hamidah Abdurrachman, 2012, Disparitas Putusan Hakim dalam Kasus Narkoba, Jurnal, Pandecta. Volume 7.Nomor 2.Juli 2012, Universitas Negeri Semarang

Books:

[1] Abdulkadir Muhamad, Segi Hukum Lembaga keuangan dan Pembiayaan, (Bandung: Citra Aditya Bakti, 2000) Muchdarsyah Sinungan, Manajemen Dana Bank (Bumi Aksara, 2000) .

[2] Achmad Sulchan, Sukarmi, Ari Widiyanto, 2017, Akta Notaris Menggunakan Media Elektronik, SINT Publishing, Kendal.

[3] Ahmad Azhar Basyir, 2000, Asas-Asas Hukum Muamalat (Hukum Perdata Islam), Edisi Revisi, Cetakan Kedua, UII Press, Yogyakarta.

[4] Ahmadi Miru, Sakka Pati, 2008, Hukum Perikatan,Rajawali Pers, Jakarta.

[5] Ahmadi Miru, 2007, Hukum Kontrak dan Perancangan Kontrak, Rajawali Pers, Jakarta.

[6] Akhmad Khisni, 2017, Hukum Waris Islam, Print. IV, Unissula Press, Semarang.

[7] Asikini Zainal, 2012, Pengantar Tata Hukum Indonesia, Raja Wali Press, Jakarta.

[8] Jonaedi Efendi, 2018, Metode Penelitian Hukum Normatif dan Empiris, Prenada Media Group, Jakarta.

[9] Kasmir. 2012, Bank dan Lembaga Kuangan Lainnya, PT. Raja Grafindo Persada, Jakarta.

[10] Purwadi Patrik dan Kashadi, 2001, Hukum Jaminan, Fakultas Hukum UniversitasDiponegoro, Semarang. 
[11] Soegianto, 2015, Etika Profesi dan Perlindungan Hukum Bagi Notaris, CV. Farisma Indonesia, Yogjakarta.

[12] Soerjono Suekanto, dan Sri Mamudi, 2003, Penelitian Hukum Normative Suatu Tinjauan Singkat, Raja Grafindo Persada, Jakarta.

[13] Supriadi, 2006, Etika \& Tanggung Jawab Profesi Hukum di Indonesia, Sinar Grafika, Jakarta.

[14] Theo Huijber, 1995, Filsafat Hukum Dalam Lintasan Sejarah, Print. VIII, Kanisius, Yogyakarta.

[15] Wahbah al-Zuhayliy, 2011, al-Fiqh al-Islamiy wa Adillatuhu, Juz .IV, Gema Insani, Jakarta

[16] Zaenal asikin, 1997, Pokok-Pokok Hukum Perbankan, Jakarta.

Regulations:

[1] Act No. 1 of 2004 concerning the State Treasury Act No. 37 of 2004 concerning Bankruptcy and Suspension of Debt Payment Obligations.

[2] Act No. 2 of 2014 amendments to Act No. 30 of 2004 concerning the Position of a Notary.

[3] Act No.: 10 of 1998 concerning Banking (Amendment toon Act No.: 7 of 1992 concerning Banking).

[4] Act No.: 4 of 1996 concerning Mortgage Act No. 10 of 1998 concerning Collateral or Collateral in Banking.

[5] Act No.: 49 of 1960 concerning PUPN (State Receivable Affairs Committee).

[6] Act No.: 5 of 1960 concerning Basic Regulations on Agrarian Principles.

[7] Act Number: 14/1967 concerning Banking Principles Decree of the Board of Directors of Bank Indonesia Number 23/69/KEP/DIR dated February 28, 1991.

[8] Code of Civil law

[9] Perma Number: 02 of 1962 concerning Procedures for Implementing the Confiscation of Immovable Goods.

Internet:

www.tegalkota.go.id, accessed on September 28, 2020 at 19.15 WIB 
Interview:

[1] Christian, SH., M.Kn, Notary in Tegal City, personal interview on June 15, 2021.

[2] Mr. Yunanto Dwi Harry Laksono, as An Account Officer NPL Bank BRI Tegal Branch Office, personal interview on June 16, 2021. 